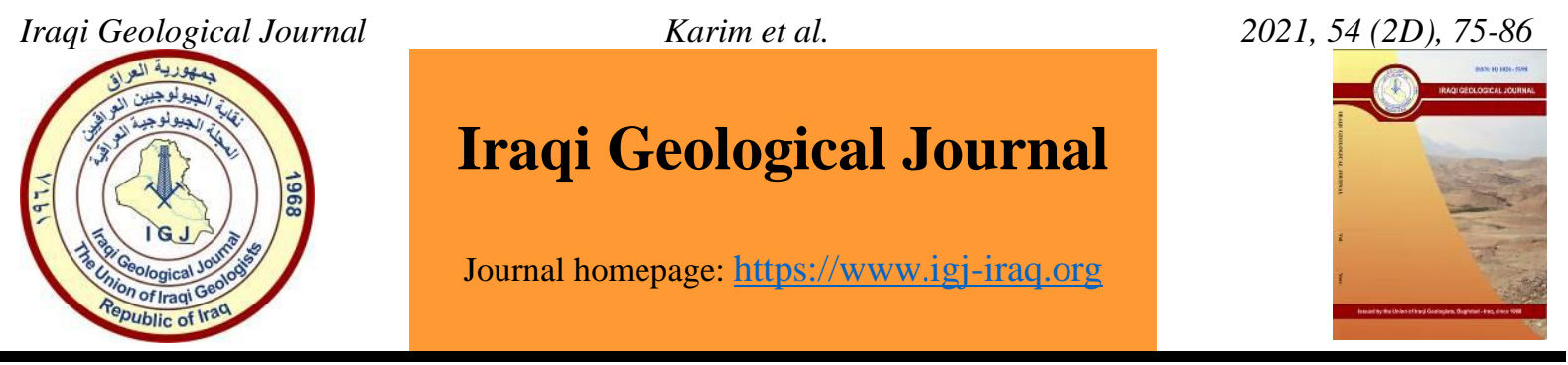

\title{
Stratigraphy and Nannofossil Biozonation of Sarmord Formation on the Qaywan Anticline, in Sulaymaniyah Governorate Northern Iraq
}

\author{
Kamal Haji Karim ${ }^{1}$, Salam Ismail Al-Dulaimy ${ }^{2, *}$, Pshtiwan Majeed Ahmad ${ }^{1}$, Omar Al-Badrani ${ }^{3}$ \\ Department of Geology, University of Sulaimani, Iraq \\ Department of Geology, College of Science, University of Baghdad, Iraq \\ Departments of Geology, College of Science, University of Mosul, Iraq \\ * Correspondence: salamgeo2018@gmail.com
}

Received: 23 June 2021; Accepted: 3 August 2021; Published: 31 October 2021

\begin{abstract}
The Sarmord Formation is one of the overlooked formations that require more investigations than that achieved before. There are many problems in its definition, age, stratigraphy and aerial distribution. Previously in most parts of the Sulaymaniyah, it is not mapped and its outcrops combined with Balambo Formation while in the present study it is differentiated, mapped in the field on the Qaywan anticline and its problems discussed in detail with a suggestion of solutions. For laboratory studies, 31 samples are taken on the Qywan Mountain (anticline) at $23 \mathrm{~km}$ north of the Sulaimani city for nannofossils biozonation. This study identified 19 species of the recorded calcareous nannofossils, the studied section reveals three biozones arranged from oldest to youngest as follows: Cretarhabdus loriei Interval Biozone, Lithraphidites bollii Interval Biozone, Micrantholithus hoschulzii Interval Biozone. These nannobiozones are correlated with other calcareous nannofossils biozones from both local and regional sections leading to conclude the age of Late Valanganian to Barremian.
\end{abstract}

Keywords: Sarmord Formation; Qaywan anticline; Balambo Formation; Calcareous nannofossils; Iraq

\section{Introduction}

The Sarmord Formation (Valanginian-Barremian) is one of the less explored formations in Iraq that require more studies than that done before. There are many problems in its original definition, age, lithology, stratigraphy and aerial distribution. Previously in most parts of the Sulaymaniyah it is not mapped and its outcrops combined with Balambo Formation. According to Bellen et al. (1959), the Sarmord Formation was defined in the core of the Surdash anticline, in Dokan area, northeastern Iraq. The definition includes $455 \mathrm{~m}$ of thickness, which consists of brown and bluish marl (of light-yellow weathering color) with some neritic limestones. Stratigraphically, the Sarmord Formation lies between Qamchuqa and Balambo formations at the top and base respectively with conformable contact with both formations.

On the Qaywan Azmir and Goizha anticlines, although it has the same lithologies of its type section, it is not differentiated previously and included in the Balambo Formation. Recently many articles are published that are differentiated the Sarmord Formation from the Balambo Formation on the Azmir and Goizha anticlines directly at the southeast of the Qaywan anticline (Fig.1), these articles are Karim et DOI: $10.46717 /$ igj.54.2D.6Ms-2021-10-25 
al. (2013), Karim and Ahmad (2014), Karim and Khanaqa (2016) and Karim et al.(2020). The present study focuses on the age, stratigraphy, field mapping and lithology of the formation in the Qaywan valley that is not studied before (Figs.2 and 3). It tries to discuss the problems that are associated with its definition and establishing a connection between the formations in Qaywan area with other areas of its occurrence.

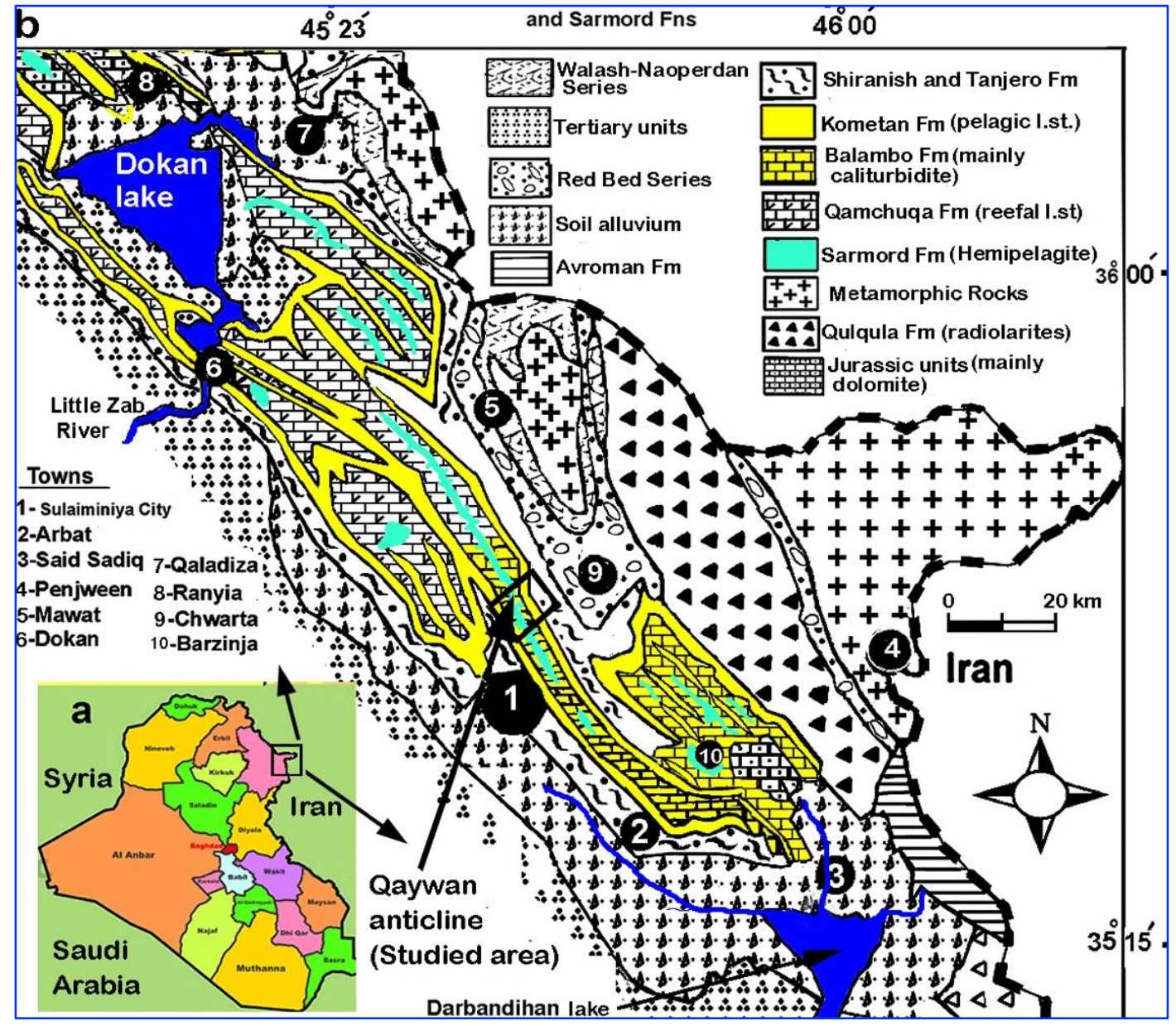

Fig.1. Location and geological map of the studied area (Karim et al., 2011)

\section{Location and Geology of the Study area}

The midpoint of the studied outcrop section is located geographically at the northern latitudes $35^{\circ}$ $42^{\prime}$ 53.94" and eastern longitudes $45^{\circ} 25^{\prime} 16.34$ ' ' in Sulaimaniya, Kurdistan Region at the northeastern Iraq (Figs.1 and 2). The section is located about $20 \mathrm{~km}$ north of Sulaimani city between the Little and Major Qaywan villages and can be reached via unpaved road that led the peak to the Shakha Sur Mountain (Figs.2 and 3). Structurally, the section located in the core of NW-SE trending Qaywan anticline, which includes several small folds. The anticlines are continuation of the northwestern end of the Azmir-Goizha anticline. The core of the anticline occupied by the Sarmord Formation (about $400 \mathrm{~m}$ thick) while along their inner and outer arcs, the Balambo and Kometan formations are exposed (Figs. $2,3,4,5$ and 6). The thicknesses of the latter two formations are 300 and 80 meters respectively.

The core transformed to deep and long valley (Qaywan valley) from which several smaller ones are branched toward northeast and collected runoff into Mokaba Stream. Tectonically, the area is a part of the Imbricate Zone in the Zagros Collisional Belt which is developed from colliding of the Arabian and Iranian Plate (Jassim \& Goff, 2006). Karim et al. (2014) studied the structure of the area in detail 
and concluded that the mountain (anticlines) chain Qaywan, Azmir, Giozha are better to be included in High Folded Zone rather than Imbricated zone. This latter study confirmed development of the anticline by detachment folding and absence of the piggy-back imbricate structure (listric thrust faults) of Ibrahim (2009) and Al-Hakari (2011). Actually, the geologic cross section of the present study does not show any thrust fault and the observed structures are parasitic fold dominated anticline (Figs.3 and 4). Karim et al. (2020) studied the Qywan area structurally and concluded that the axes of small folds (parasitic folds) are deviated (shifted) from the axes of main folds of the Zagros Belt for about 20 degrees northward (Fig.7b and c). They attributed this deviation to facies change (Fig.6) in the area in addition to the effect of Mawat Complex.

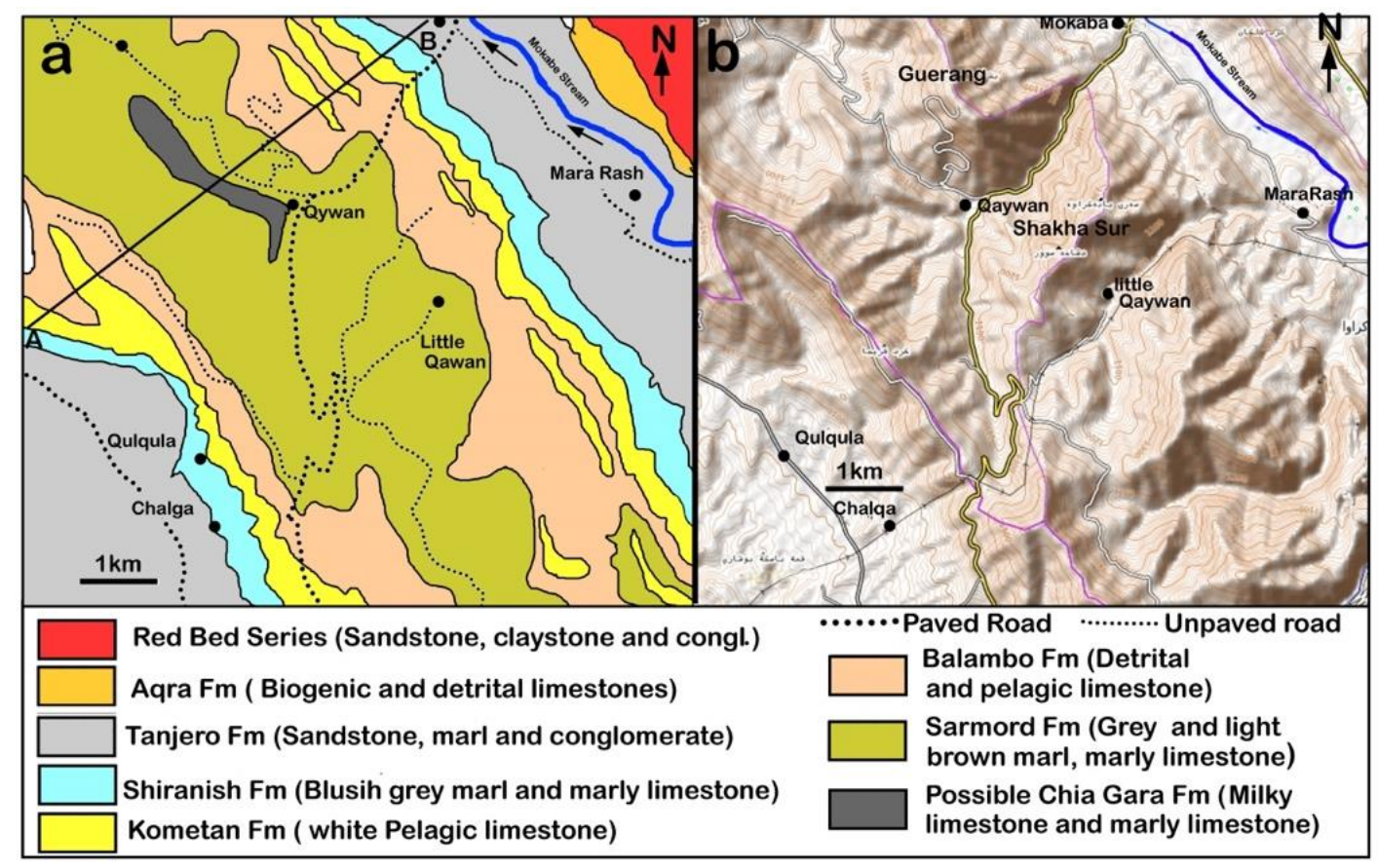

Fig.2. Geological map of the Qaywan valley of the present study (a) and its base map (b)

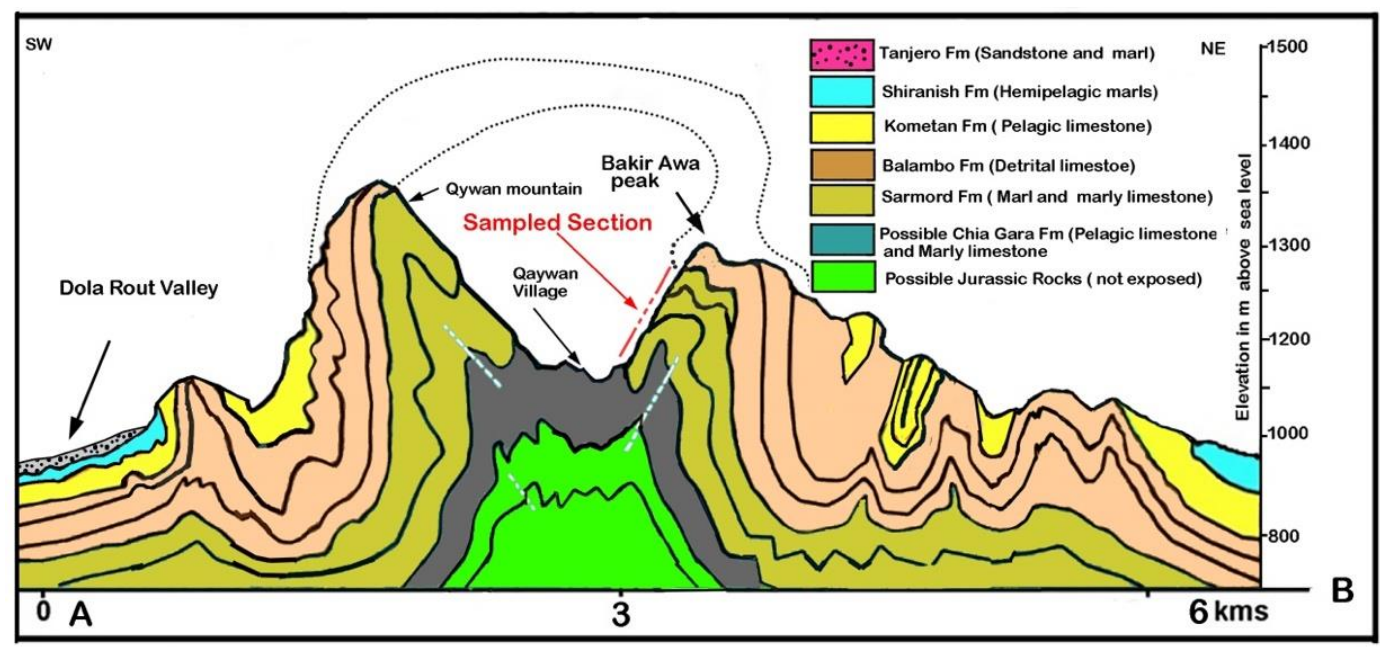

Fig.3. Geologic Cross section of the Qaywan Mountain shows sampled section 


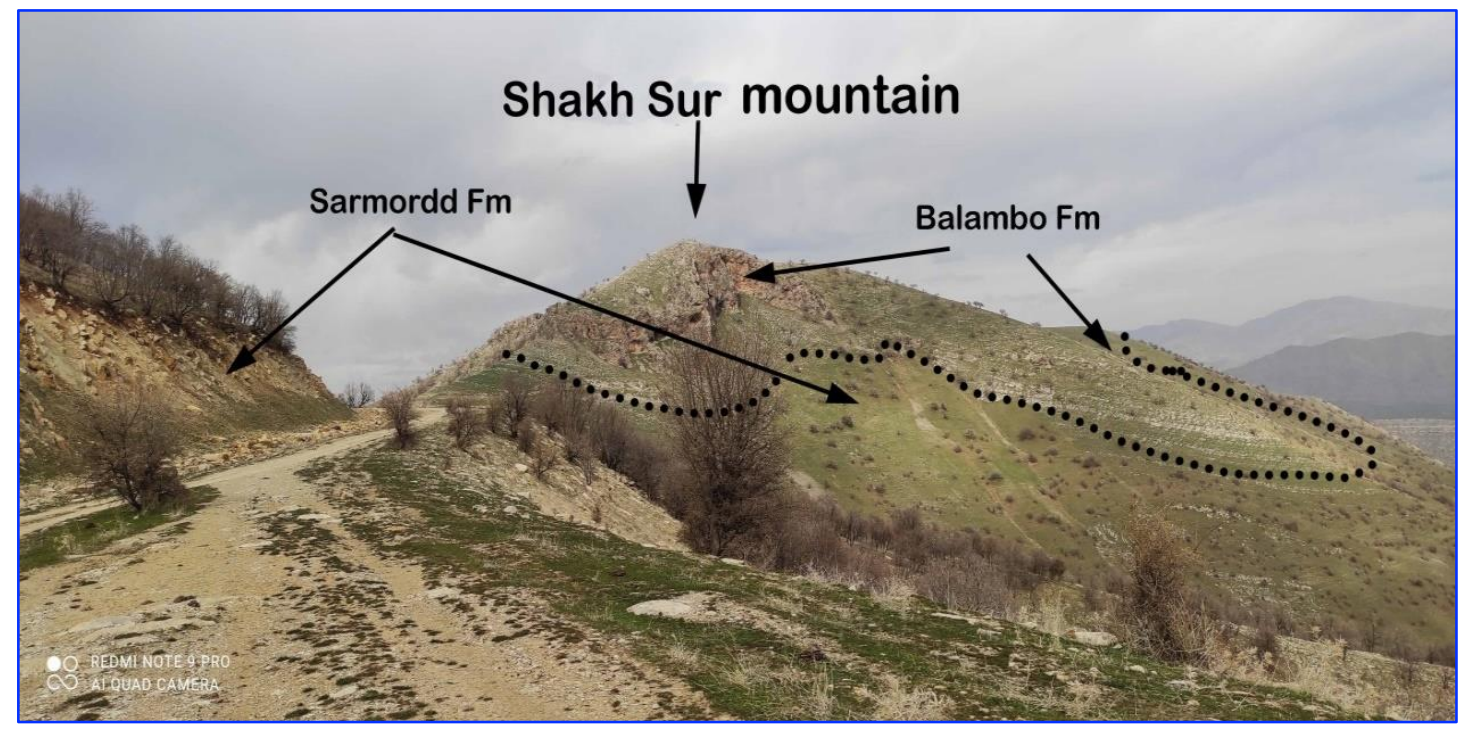

Fig.4. General view of the Qaywan Mountain with exposed formations

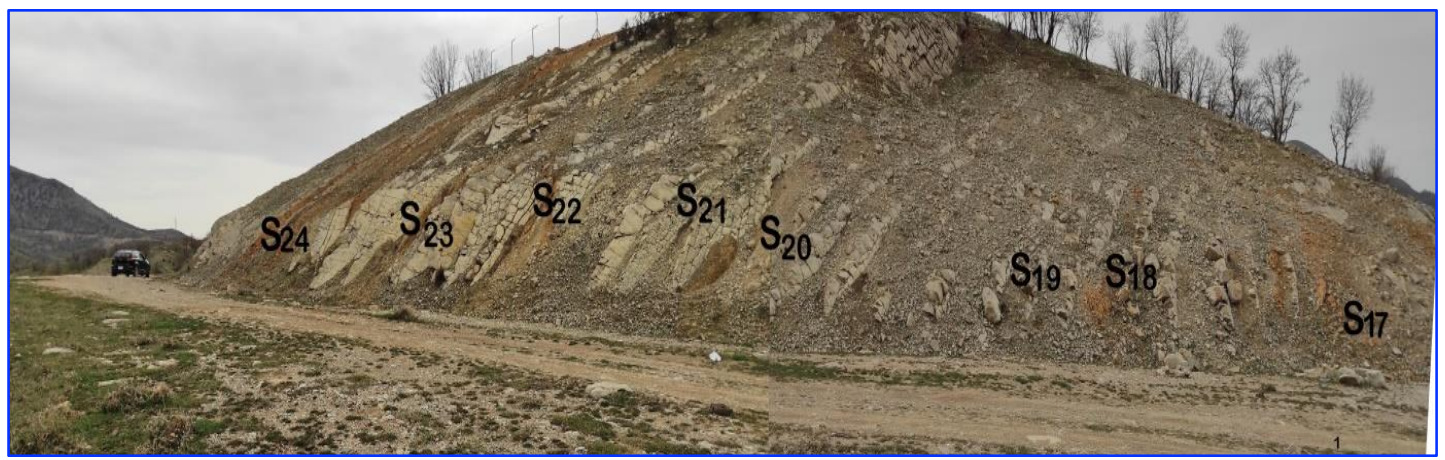

Fig.5. The studied section and location of the eight samples of the Sarmord Formation

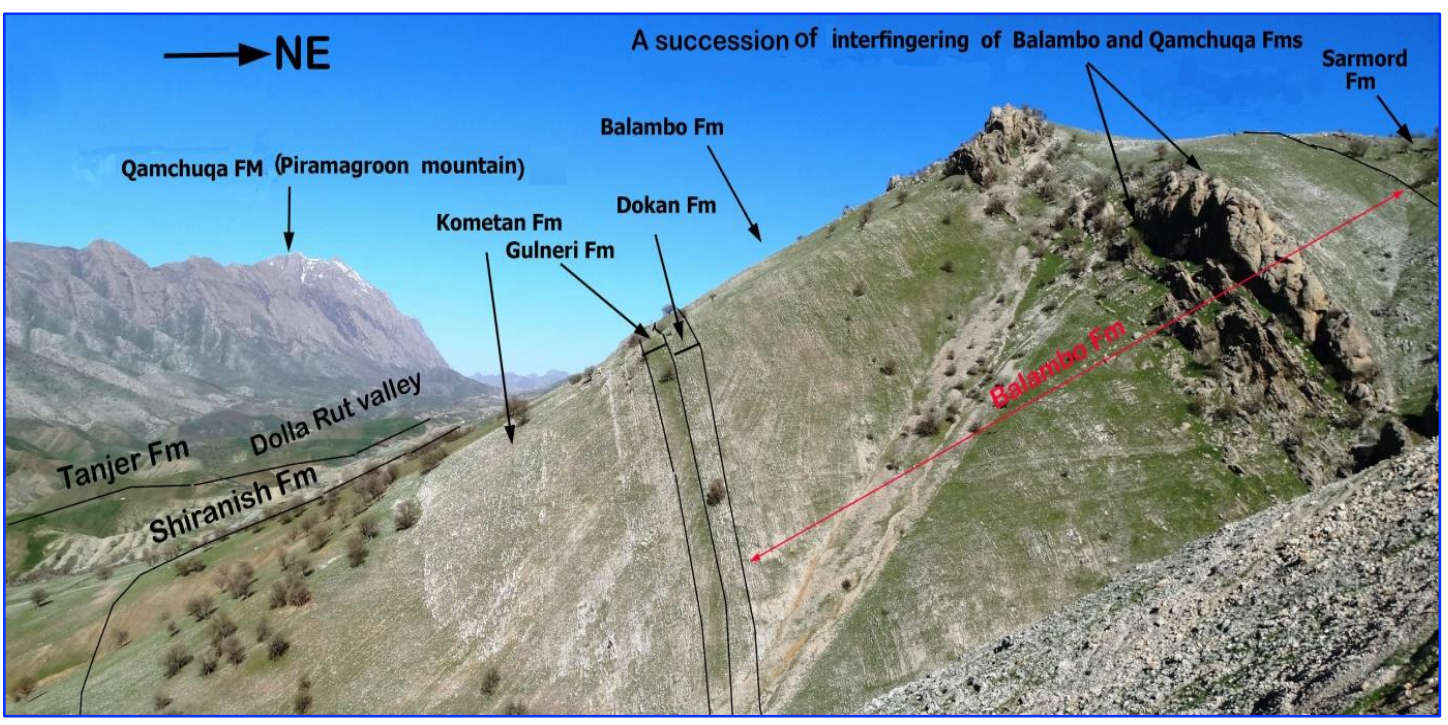

Fig.6. General view of the outer arc (southwestern limb) of the Qywan anticline shows outcropped formations 


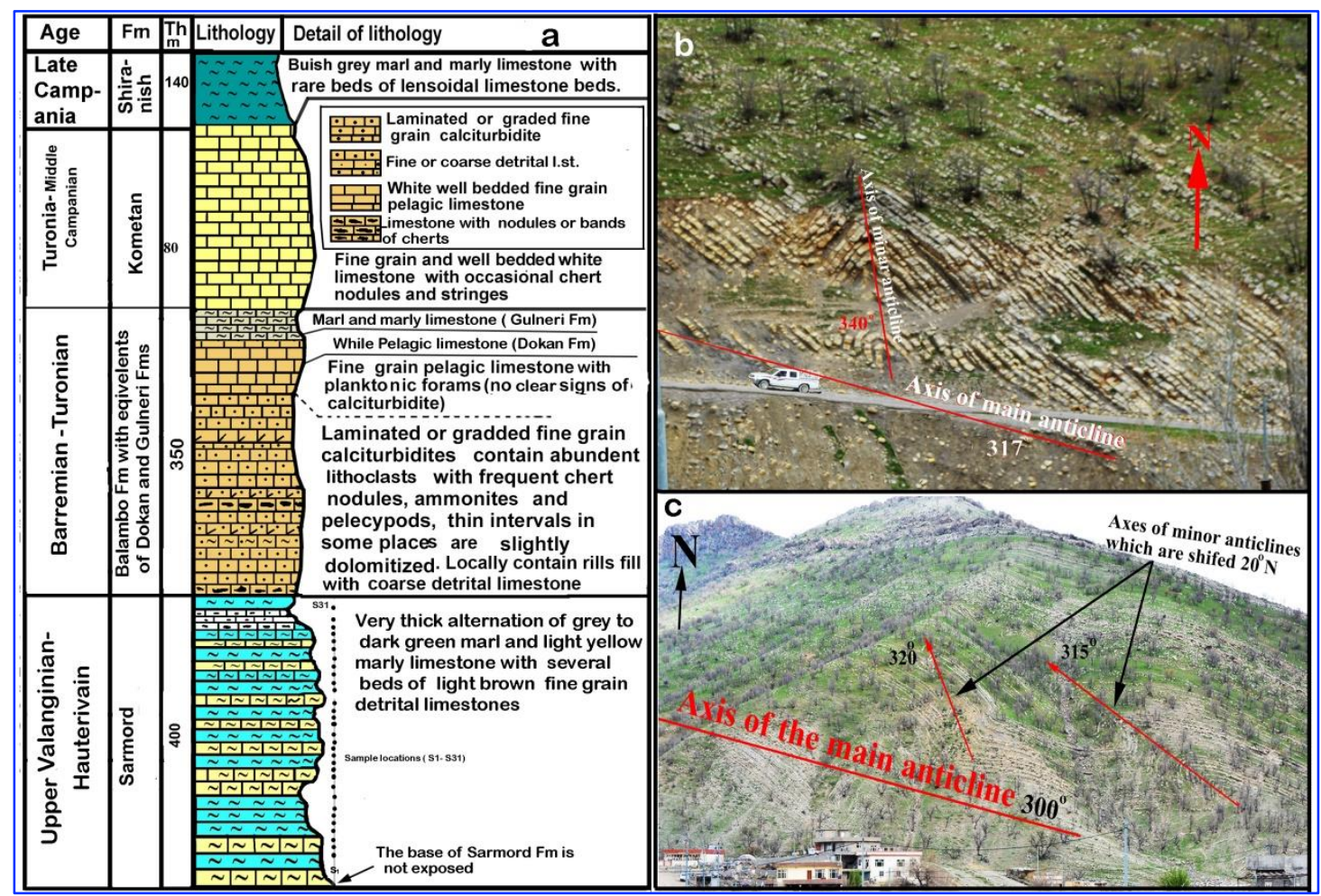

Fig.7. (a) Stratigraphic column of the Qaywan Mountain at $20 \mathrm{~km}$ north of Sulaimanyiah city shows the locations of the studied samples. ( $b$ and c) two photos of Karim et al. (2020) show the shifting of the small anticlines 20 degrees toward the north relative to the axis of main anticlines at the northwestern boundary of Qaywan valley

\section{Materials and Methods}

This study focused on the Qaywan valley (as core of an anticline with the same name) which is mapped in the field; cross section and stratigraphic column are drawn for the first time (Figs. 3 and 7). The Sarmord Formation is differentiated for the first time in the valley and its contacts are delineated. For lab works we took, 31samples of marls and marly limestone for the studying the calcareous nanno fossils using the thin section (under transmitted-light microscope). The calcareous nannofossils are extracted by using the method $(\mathrm{H})$ (Armstrong and Brasier, 2005). Due to its softness, the sampling and true thickness measurement of the formation are difficult and it covered by soils in most places. It exhibits many refolding and plastic deformations, which developed by tectonic stresses (Figs.3, 7b, and c). Due to these reasons, we are not sure, if there are repetitions and if the lower contact is samples or not. Where, the outcrops are available, the samples are taken in interval of $4 \mathrm{~m}$ but in some interval this method is not followed due to soil covering.

\section{Results}

\subsection{Systematic Paleontology Heterococcolith}

Family Chiastozygaceae Rood, Hay and Barnard, 1973

Genus Chiastozygus Gartner, 1968

Chiastozygus striatus Black, 1959

Genus Zeugrhabdotus Reinhardt, 1966

Zeugrhabdotus embergeri (Noël, 1958) Perch-Nielsen, 1984

Family Cretarhabdaceae Thierstein, 1973 
Genus Cretarhabdus Bramlette and Martini, 1964

Cretarhabdus loriei Gartner, 1968

Genus Cruciellipsis Thierstein, 1971

Cruciellipsis cuvillieri (Manivit, 1966) Thierstein, 1971

Genus Retecapsa Black, 1971

Retecapsa crenulata (Bramlette and Martini, 1964) Noel, 1970

Genus Speetonia Black, 1971

Speetonia colligate Black, 1971

Family Rhagodiscaceae Hay, 1977

Genus Calcicalathina Thierstein, 1971

Calcicalathina oblongata (Worsley, 1971) Thierstein, 1971

Family Watznaueriaceae Rood et al., 1971

Genus Tubodiscus Thierstein, 1973

Tubodiscus verenae Thierstein, 1973

Genus Watznauria Reinhardt, 1964

Watznaueria barnesae (Black and Barnes, 1959) Perch-Nielsen, 1968

- Holococcolith

Family Calyptrosphaeraceae Boudreaux and Hay, 1969

Genus Calculites Sissingh, 1977

Calculites anfractus (Jakubowski, 1986) Varol and Jakubowski, 1989

III- Nannolith

Family Braarudsphaeraceae Deflandre, 1947

Genus Braarudosphaera Defladre, 1947

Braardosphaera regularis Black, 1971

Genus Micrantholithus Deflandre and Fert, 1954

Micrantholithus hoschulzii (Reinhardit, 1966) Thierstein, 1971

Micrantholithus obtusus Stradner, 1963

Family Microrhabdulaceae Deflandre, 1963

Genus Lithraphidites Deflandre, 1963

Lithraphidites bollii (Thierstein, 1971) Thierstein, 1973

Lithraphidites carniolensis Deflandre, 1963

Family Polycyclolithaceae Varol, 1992

Genus Eprolithus Stover, 1966

Eprolithus antiquus Perch-Nielsen, 1979

Family Nannoconaceae Deflandre, 1959

Genus Nannoconus Kamptner, 1931

Nannoconus colomii (de Lapparent, 1931) Kamptner, 1938

Nannoconus kamptneri Bronnimann, 1955

Nannoconus steinmannii Kamptner, 1931

\subsection{Nannobiostratigraphy}

Depending on the extracted nannofossil species (Fig.8) and their stratigraphic distribution, three biozones (Fig.9) are identified: 1-Cretarhabdus loriei Interval Biozone (CC4)

Definition: Interval from the first occurrence of Cretarhabdus loriei to the last occurrence of Speetonia colligata with a thickness of 130 meters (S. no. 9).

Discussion: This biozone is correlated with the biozone (CC4) (Cretarhabdus loriei Biozone) by Sissigh (1977) and correlated with BC5- BC10 biozones which is studied by Burnett (1998) therefore we suggested the late Valanginian to Hauterivian (Gradstein et al., 2012) 


\subsubsection{Lithraphidites Bollii Interval Biozone (CC5)}

Definition: Interval from the last occurrence of Speetonia colligata to the last occurrence of Calcicalathina oblongata with a thickness of 120 meters (S10-S20)

Discussion: This biozone is correlated with the biozone (CC5) (Lithraphidites bollii Biozone) by Sissigh (1977) and correlated with BC11- BC13 biozones which is studied by Burnett (1998) therefore we suggested the Hauterivian (Gradstein et al., 2012).

\subsubsection{Micrantholithus Hoschulzii Interval Biozone (CC6)}

Definition: Interval from the last occurrence of Calcicalathina oblongata first occurrence of Chastozygus litterarius with a thickness of 150 meters (S.no.4 -S.no. 8)

Discussion: This biozone is correlated with the biozone (CC6) (Cretarhabdus loriei Biozone) by Sissigh (1977) and correlated with BC13-BC17 biozones which is studied by Burnett (1998) therefore we suggested the Hauterivian to Berremian (Gradstein et al., 2012).

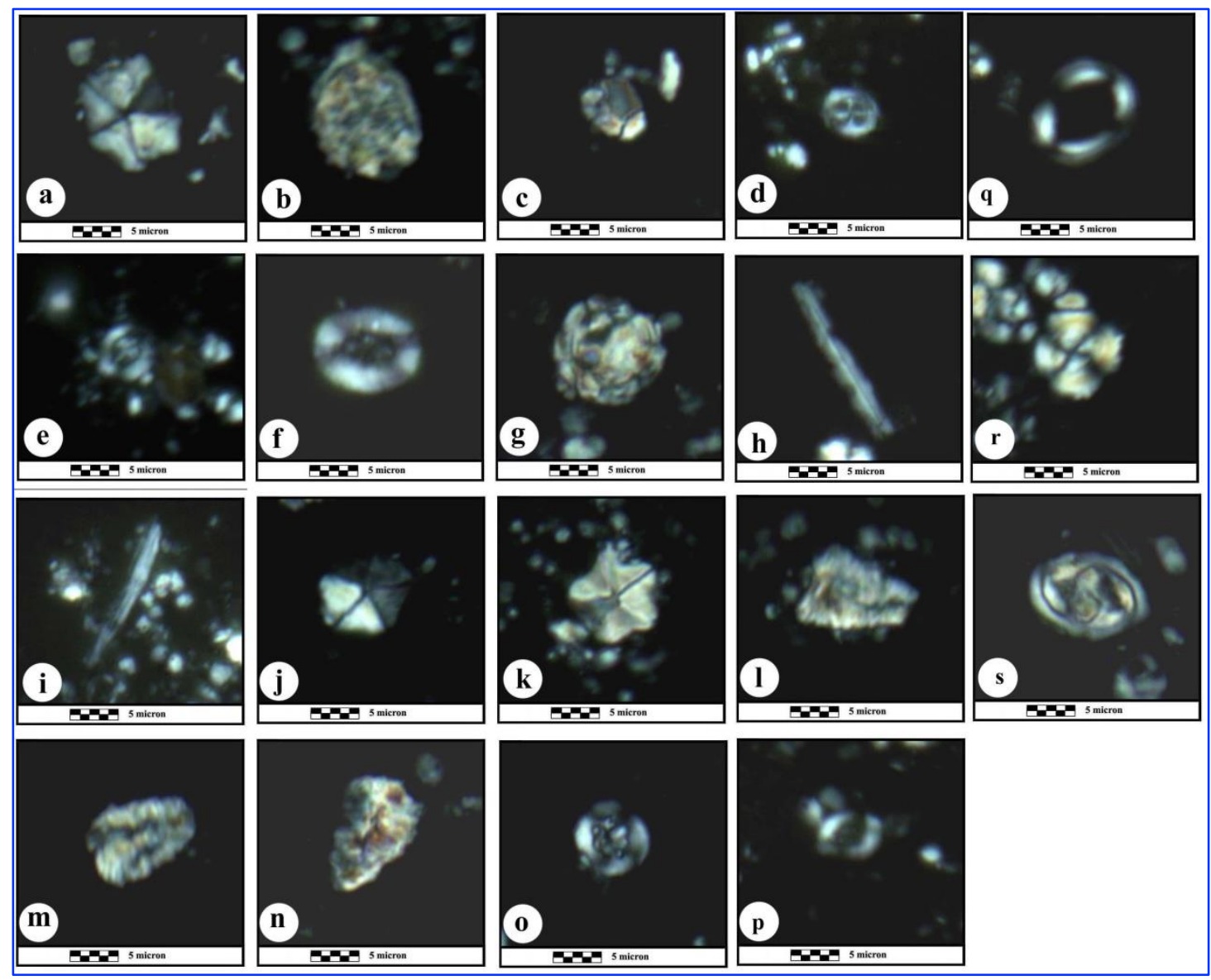

Fig.8. (a) Braardosphaera regularis, S. no.31 (b) Calcicalathina oblongata, S. no.20 (c) Calculites anfractus, S. no.13, (d) Chiastozygus striatus, S. no.31, (e) Cretarhabdus loriei, S.no.30 (f) Cruciellipsis cuvillieri, S. no.3 (g) Eprolithus antiquus, S. no.29, (h) Lithraphidites bollii, S. no.6, (i) Lithraphidites carniolensis, S. no.24, (j) Micrantholithus hoschulzii, S. no.15, (k) Micrantholithus obtusus, S. no.4, (l) Nannoconus colomiim, (m) Nannoconus kamptneri, S. no.9 (n) Nannoconus steinmannii, S. no.18, (o) Retecapsa crenulata, S. no.11, (p)Speetonia colligata, S. no. 9, (q) Tubodiscus verenae,S. no.1, (r) Watznaueria barnesae, S. no.26, (s) Zeugrhsbdatus embergeri, S. no.22 


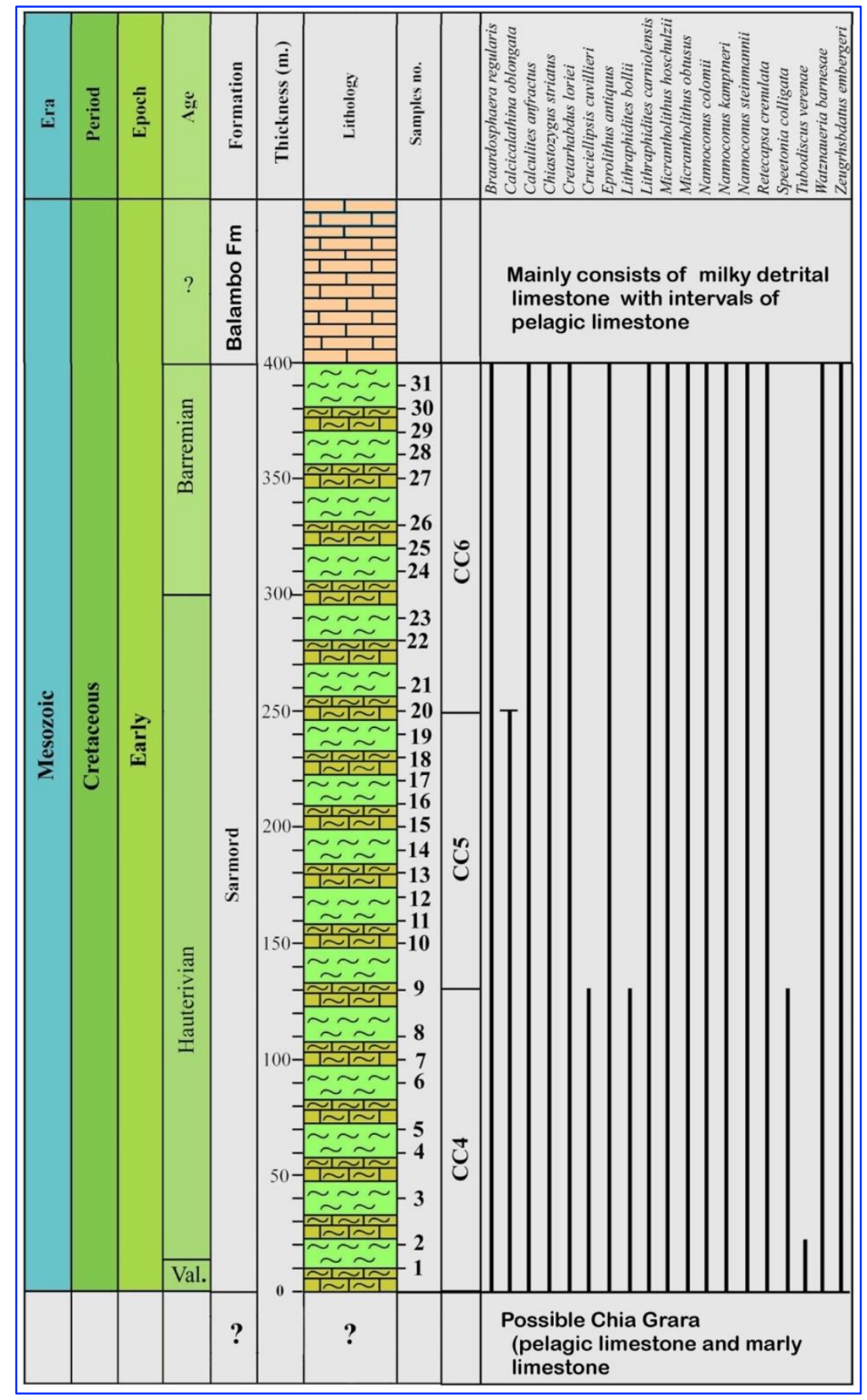

Fig.9. Range chart of calcareous nannofossils for studied section

\section{Discussion}

The Sarmord Formation is not studied adequately and has many problems; first is the combination with the Balambo Formation in the Sirwan valley on the south-eastern limb of Balambo anticline (Bellen et al., 1959). The same combining is applicable for whole Sulaimaniyah Governorate by the latter authors and most recent studies. We think that this combining is resulted from the structural complexity of the type areas (Sirwan Valley) where the Balambo Formation was defined. In the Valley, the Balambo Formation has not continuous and unified section since it defined in three different areas. Due to this complexity, Bellen et al. (1959) not recorded the Sarmord in the valley and 3 years later, in 1950, defined it in the Dokan area inside the Qamchuqa Gorges and possibly considered the Sarmord Formation as 
facies change of Balambo Formation to justify its absence and not mentioning in the Sirwan valley. In contrast to this early definition, Karim et al. (2016) concluded the occurrence of the Sarmord Formation below the Balambo Formation in the latter valley. The secondly, the definition of Sarmord has not unified and continuous type section since it defined in two different areas (similar to the Balambo Formation). Its upper part is defined inside Qamchuqa Gorge near Sarmord village while its lower part described near Sargelu village at $14 \mathrm{~km}$ to the east of the its upper part. The third is the softness of marl and marly limestone and this property makes hard to estimate its true thickness due tectonic deformations (folding, faulting and flowage) (Figs. 3, 6, 7 and 12). These deformations are more pervasive in Sulaimaniyah where the type section of the Sarmord, Qamchuqa and Balambo formations are defined for the first times. These deformations are more distinctive in areas where Sarmord occurs with Balambo Formation due to relative incompetency of the both formations to the stress. These areas such as Qaywan, Goizha, Azmir, Balambo, Shinarwe, Greza, Kura Kazhaw Mountains, eastern part of Sharbazher area, south of Mawat town, Sirwan valley, areas east and northeast of Halabja town, Qandil area and northern boundary of Sharazoor plain.

The fourth is absence of the Sarmord Formation in the above areas in Bellen et al. (1959) and on all the revision of geological maps of Iraq. Dunnington, (1958) showed by map that most parts of the Sulaimaniyah were covered by marl during Barremian-Cenomanian (Fig.11 a and b). However, the actual stratigraphy of the studied area opposes consideration of the latter authors since during these ages (Aptian, Albian and Cenomanian) there is not deposition of marls. Instead of the marls, either detrital or pelagic limestone (without marls) is deposited in the Governorate. This is proved by the works of the present study and those of Karim et al. (2013) and Karim (2020).

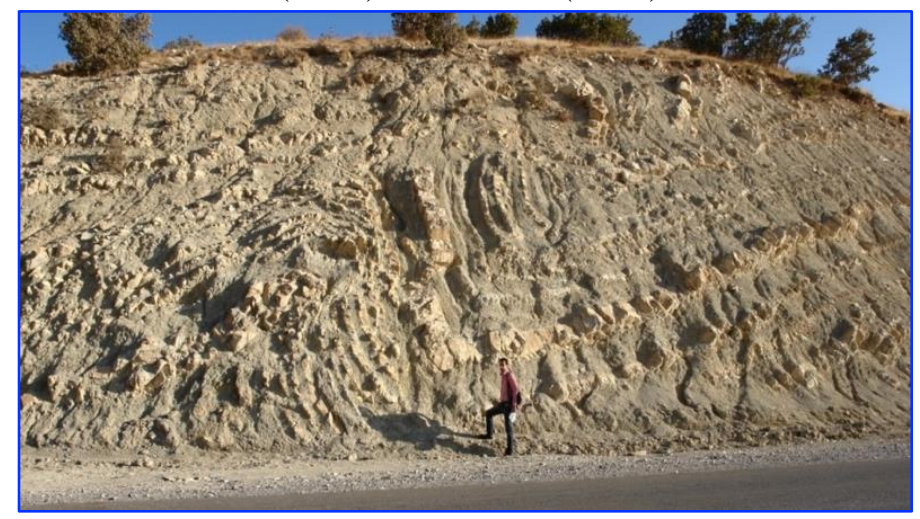

Fig.10. Lithologies (marl and marly limestone) and deformations of the Sarmord Formation on the Qaywan anticline, $20 \mathrm{~km}$ north of Sulaimani city

In these ages Qamchuqa and Balambo formations were deposited in the same times in shallow (on the platform) and in deep basin respectively (Fig.12). Before these ages (Valanginian-Barremian), the Sarmord Formation deposited in deep basin as the hemipelagic sediments (mainly marl and marly limestone) in the Sulaimaniyah. This formation has no relation with Balambo and Qamchuqa formations (as two equivalent formations). In this context, the tectonic and paleogeography of the Sarmord Formation is different too from Balambo Formation because the former one is equivalent to the Nahr Omer Formation (sandstone) while the later formation equivalent to the Qamchuqa Formation. Karim, (2020) explained in details that the Balambo Formation consisted of calciturbidite (deep detrital limestones that are deposited by turbidity currents), he added that these sediments were sourced from the Qamchuqa Formation as a platform and transported to deep basin of latter formation. However, Ali et al. (2020) refused this important finding while the field study of the present study aids the occurrence of calciturbidite in the studied area. Since, coarse detrital limestones with Bouma sequence (Bouma, 
1962) and limestone conglomerate are very common in the Balambo Formation (Two locations can be

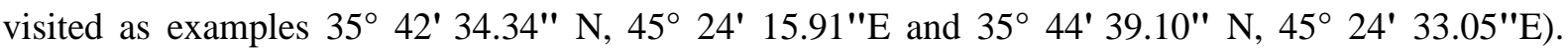
Therefore, the combing of the Sarmord with the Balambo Formation not valid for the Sulaimaniyah since, in the field, it has distinctive lithology and differentiable from Balambo Formation easily (Figs. 2 and 3). In this area, the latter formation composed nearly of pure carbonate with subsidiary marly limestone.

The fifth problem is overlapping of the age of the Sarmord and Qamchuqa formations when the age determination of Bellen et al. (1959) is considered (Fig.13). This is a serious problem since the two formation are defined in the same area (Qamchuqa Gorge), therefore the ages of two formation cannot overlap if not there is more or less error in age determination and definition. The sixth problem is the study of Basher and Al-Samarraie, (2012) who considered a succession of $80 \%$ of dolomite and limestone as the Sarmord Formation in Duhok area. The latter article recorded widespread dolomitization in the formation, which is highly contradicting the lithology of its type locality, which barren of dolomite. The seventh problem is record of lateral passage of the Sarmord into Balambo Formation toward northeastwards by Bellen et al. (1959). The field works of the present study, in the Sulaimniyah, not proved this lateral gradation. Another problem is putting the Balambo Formation under the Sarmord Formation in the Qamchuqa Gorge (its type section) by latter authors. We suggest amending this stratigraphy and indicated Chai Gara Formation under Sarmord instead to the Balambo Formation. Therefore, the present study tries to contribute solving the many problems that associated with its previous literatures via field and lab studies in addition to updating the data of the formation via nannofossil analyses.

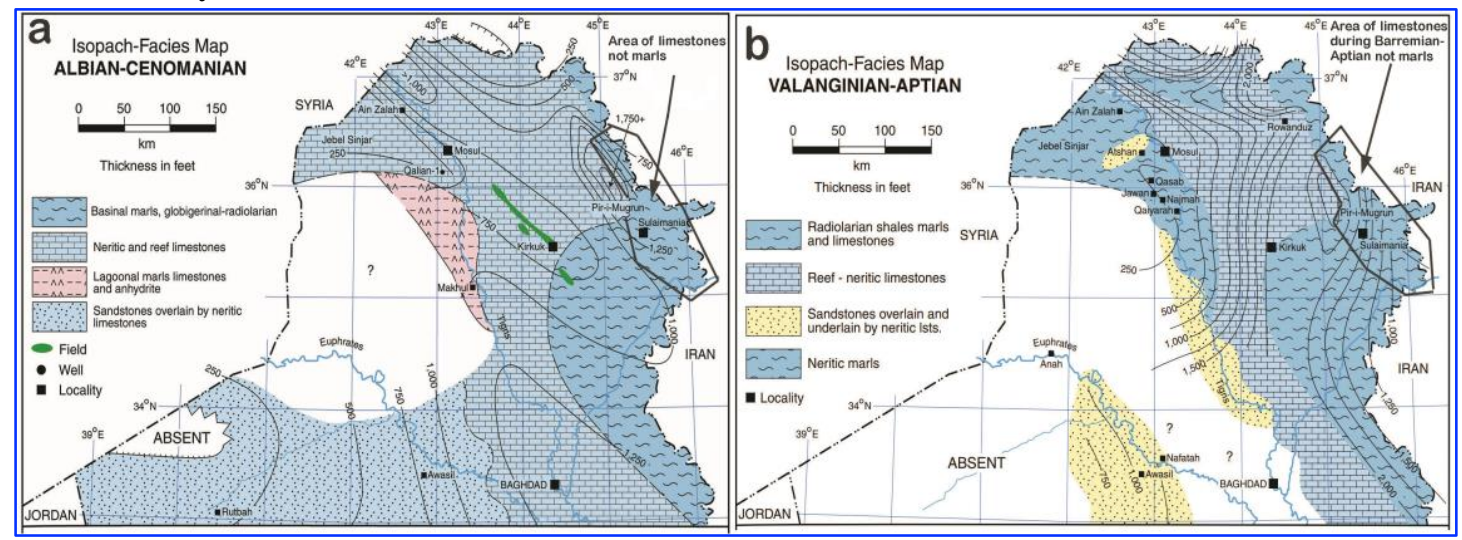

Fig.11. Isofacies maps of Dunnington (1958) for (a) Albian-Cenomanian; (b) Valanginian, Huterivian, Barremian and Aptian. The present study confirms that during these ages only during Valanginian and Barreman marls are deposited while during the rest carbonates are deposited

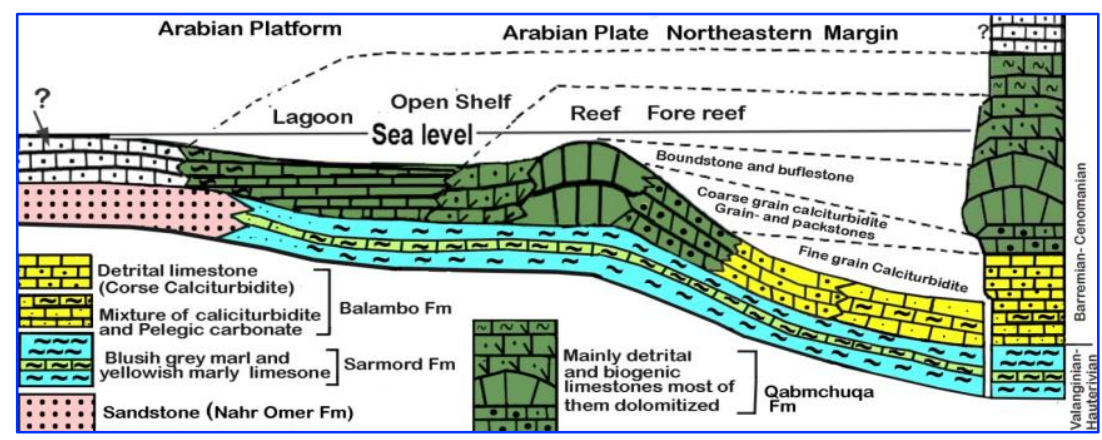

Fig.12. Paleographic and tectonic model of Sarmord, Balambo and Qamchuqa Formations during ValanginianCenomanian 


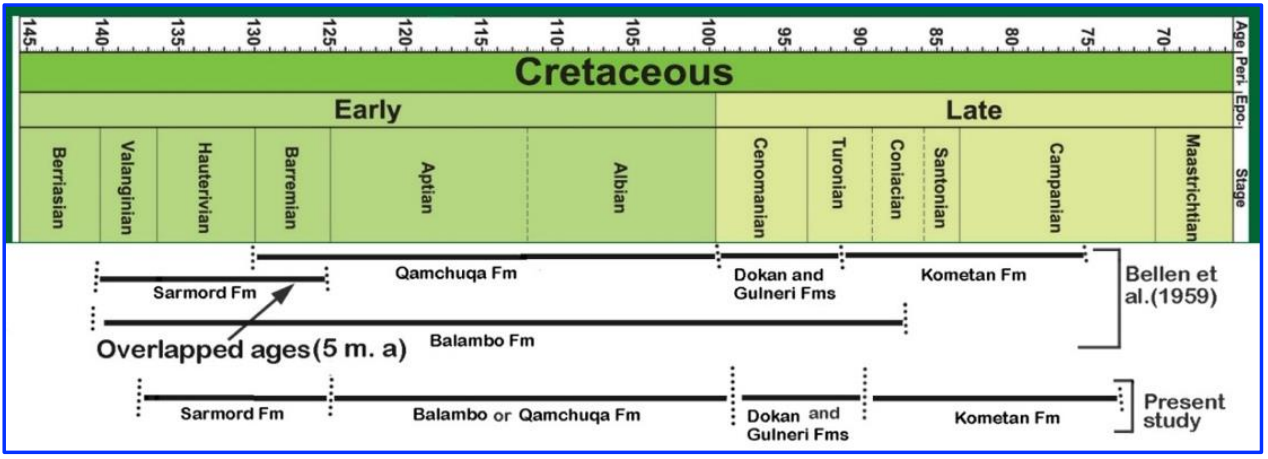

Fig.13. Ages of most of the Cretaceous Formation in the Sulaimaniyah (Bellen et al., 1959) and present study. It is observable that the ages of Sarmord and Qamchuqa formations are overlapping although they define in the same area (Qamchuqa Gorge

\section{Conclusions}

The Balambo and Sarmord formations have distinctive and different llithologies in Sulaimaniyah, which must be differentiated, and their combination is amended. In Qaywan valley, we mapped the Sarmord Formation for the first time and indicated its contacts. The study discussed many stratigraphic, lithologic and chronologic problems of the Sarmord Formation and suggested to be under consideration in future studies. Based on stratigraphic ranges of the recorded calcareous nannofossils we determined three biozones arranged from oldest to youngest as follows: Cretarhabdus loriei Interval Biozone (CC4), Lithraphidites bollii Interval Biozone (CC5), Micrantholithus hoschulzii Interval Biozone (CC6). Our study correlated these biozones with other calcareous nannofossils biozones from both local and regional sections leading to conclude the age of Late Valanginana- Barremian.

\section{Acknowledgements}

The authors are very grateful to the Editor in Chief Prof. Dr. Salih M. Awadh, the Secretary of Journal Mr. Samir R. Hijab. and the Technical Editors for their great efforts and valuable comments.

\section{References}

Al-Hakari, S. H. S., 2011.Geometric analysis and structural evolution of NW Sulaimani Area, Kurdistan Region, Iraq. Unpublished Ph.D. Thesis, University of Sulaimani, 309 pp.

Ali, S.A., Mohammad, Y.O., Lawa, F.A., Baziany, M.M., Al-Juboury, A.I., 2020. Early Cretaceous calciturbidites facies from Zagros FoldThrust belt: a key to paleogeography and environment of northeast Arabian Platform Passive Margin, Kurdistan Region, Northeast Iraq, Carbonates and Evaportites.

Armstrong, H. A. \& Brasier, M. D., 2005. Microfossils, 2nd ed. Malden, Oxford, Carlton, 296.

Basher, W. P., and and Al-Samarraie, B. A., 2012. Petrograhpic study of the Sarmord Formation in North Zakho area, NW IRAQ, Iraqi Bulletin of Geology and Mining, 8 (2), 45-63.

Bellen, R. C.V., Dunnington, H., Wetzel, R., Morton, D., 1959. Lexique Stratigraphique. Asie, Iraq, 333.

Black, M., and Barnes, B., 1959. The structure of Coccoliths from the English Chalk Geological Magazine, 96 : 321-328.

Black, M., 1971. Coccoliths of the Speeton Clay and Sutterby Marl. Proceedings of the Yorkshire Geological Society, 38 (18), 381-424.

Bouma, A.H., 1962. Sedimentology of some Flysch deposits: A graphic approach to facies interpretation, Elsevier, Amsterdam, 168.

Bramlette, M. N., and Martini, E., 1964. The great change in calcareous nannoplankton fossils between the Maastrichtian and Danian. Micropaleontology, 10 (3), 291-322.

Deflandre, G., 1959. Sur les nannfossiles calcaires et leur systematique. Rev. Micropaleontology, 2 (3),127-152. 
Deflandre, G., 1963. Sur les Microrhabdulidés, famille nouvelle de nannfssiles calcaires, Paris, 256, 3484-3486.

Deflandre, G., and Fert, C., 1954. Observation sur les coccolithophoridés actuels et fissiles en microscope ordinaire et electronique. Annales de Paléontologie, 40, 115-176.

Dunnington, H.V., 1958, Generation, migration, accumulation, and dissipation of oil in Northern Iraq, in Habitat of Oil: American Association Petroleum Geologists, 1194-1251.

Gartner, S., 1968. Coccoliths and related calcareous nannofossils from Upper Cretaceous deposits of Taxas and Arkansas. University Kansas Paleontology Contribution-Protista, Artical1, 1-56.

Gradstein, F. M., Ogg, J. G., Schmitz, M. D. and Ogg, G., M., 2012. The geologic time scales. The Boulevard, Langford lane, Kidlington, Oxford OX5 1GB, UK, 2, 437-1144.

Jassim, S. Z., Goff, J.C., 2006. Geology of Iraq. Dolin, Prague and Moravian Museum, Brno, 341.

Ibrahim, A.O., 2009. Tectonic style and evolution of the NW segment of the Zagros Fold Thrust Belt, Sulaimani Governorate, Kurdistan Region, NE Iraq. Ph. D. Thesis, University of Sulaimani, 187.

Karim, K.H., 2020. Early Cretaceous calciturbidites facies from Zagros Fold Thrust belt: a key to paleogeography and environment of northeast Arabian Platform Passive Margin, examples from Kurdistan Region, Northeast Iraq. Carbonates and Evaporites, 35(1),1-18.

Karim, K. H. and Ahmad, S.H., 2014. Structural analysis of the Azmir-Goizha anticline, north and northeast of Sulaimani city, Kurdistan Region, Northeast Iraq, Journal of Zankoy Sulaimani, 16 (1), 45-68.

Karim, K.H., Koyi, H., Baziany, M.M., and Hessami, K., 2011. Significance of angular unconformities between Cretaceous and Tertiary strata in the northwestern segment of the Zagros Fold Thrust belt, Kurdistan Region, NE-Iraq. Geological Magazine, Cambridge University Press, 148(6/5), 925-939.

Karim, K.H., and Khanaqa, P.A., 2016. Lithology and stratigraphy of the Cenomanian/ Turonian boundary in Zagros orogenic belt: examples from Kurdistan Region, Northeastern Iraq, Iraqi Geological Journal, 39 (2), 73-90.

Karim, K. H., Khanaqa, P.A., Ismail, K.M., 2020. Role of facies changes in shifting trends of anticlines in the Zagros Fold-Thrust belt: Examples from Sulaimani area, Kurdistan Region, northeastern Iraq, Journal of Zankoy Sulaimani, 22(1), 1-28.

Karim, K. H., Salih, A.O. and Ahmad, S. H., 2013. Stratigraphic analysis of Azmir-Goizha anticline by Nannofossils, Journal of Zankoy Sulamani, 15 (2), 103-124.

Karim, K. H., Al-Khafaf, A. O., and Sharnazheri, K. I., 2016. Critical analysis of the type section of the Balambo Formation (Valanganian-Turonian), Sirwan valley, Kurdistan Region, NE-Iraq, Journal of Zankoi Sulaimani, 189-202

Perch-Nielsen, K., 1968. Der feinbau und die klassifikation der coccolithen aus dem Maastrichtien von Danemark. Kong. Danske videnskab. Selskab,16: 1-96.

Perch-Nielsen, K., 1979. Calcareous nannofossils from the Cretaceous between the North Sea and the Mediterranean. Aspekte der Kreide Europas, 6, 223-272.

Reinhardt, P., 1964. Einige alkaflagellaten-gattungen Coccolithophoriden, Coccolithineen) aus dem Mesozoikum deutschlands. Monatsber. Deutsch.a Akad. Wiss. Berlin, 6, 749-759.

Reinhardt, P., 1966. Zur taxionomie und biostratigraphie des fossilen nannoplanktons aus dem malm, der kreide und dem attertiar Mitteleuropas. Freiberger Forschungshefte, Palaontologie, Series C, 196, 513 - 524.

Rood, A.P.; Hay, W.W. and Barnard, T., 1971. Electron microscope studies of oxford clay Coccoliths. Eclogae Geologicae Helvetiae, 64, 245-272.

Sissigh, W., 1977. Biostratigraphy of Cretaceous calcareous nannoplankton. Geological Mining, 56, 37-65.

Stover, E., 1966. Cretaceous coccoliths and associated nannofossils from France and Netherlands. Micropaleontology, 12 (2),133-167.

Stradner, H., 1963. New contributions to Mesozoic stratigraphy by means of nannofossils. Proceedings of the Sixth World Petroleum Congress, 167-183.

Thierstein, H. R., 1973. Lower Cretaceous calcareous nannoplankton biostratigraphy, 29, 52.

Worsley, T. R., 1971. Calcareous nannofossil zonation of Upper Jurassic and Lower Cretaceous sediments from the Western Atlantic. In: Farinacci, A. (Editor), Proceedings of the Second Planktonic Conference Roma 1971. 2 Edizioni Tecnoscienza, Rome, 1301-1321 